\title{
Presynaptic Mechanism for Phorbol Ester-Induced Synaptic Potentiation
}

\author{
Tetsuya Hori, ${ }^{1}$ Yoshimi Takai, ${ }^{2}$ and Tomoyuki Takahashi ${ }^{1}$ \\ ${ }^{1}$ Department of Neurophysiology, University of Tokyo Faculty of Medicine, Tokyo 113-0033 Japan, and 2Department of \\ Molecular Biology and Biochemistry, Osaka University Medical School, Suita 565-0871 Japan
}

Phorbol ester facilitates transmitter release at a variety of synapses, and the phorbol ester-induced synaptic potentiation (PESP) is a model for presynaptic facilitation. To address the mechanism underlying PESP, we have made paired whole-cell recordings from the giant presynaptic terminal, the calyx of Held, and its postsynaptic target in the medial nucleus of the trapezoid body in rat brainstem slices. Phorbol ester potentiated EPSCs without affecting either presynaptic calcium currents or potassium currents. Protein kinase $\mathrm{C}$ inhibitors applied from outside or injected directly into the presynaptic terminal attenuated the PESP. Furthermore, presynaptic loading of a synthetic peptide with the sequence of the N-terminal domain of Doc2 $\alpha$ interacting with Munc13-1 (Mid peptide) significantly attenuated PESP, whereas mutated Mid peptide had no effect. We conclude that the target of the presynaptic facilitatory effect of phorbol ester resides downstream of calcium influx and may involve both protein kinase $\mathrm{C}$ and Doc2 $\alpha$ - Munc13-1 interaction.

Key words: phorbol ester; synaptic facilitation; Doc2 $\alpha$; Munc13-1; protein kinase C; the calyx of Held; presynaptic recording
Phorbol ester enhances synaptic efficacy by increasing transmitter release at a variety of synapses (Malenka et al., 1986; Shapira et al., 1987). This presynaptic facilitatory effect of phorbol ester is thought to be mediated by protein kinase C (PKC) through (1) activation of calcium channels (Fossier et al., 1990; O'Dell and Alger, 1991; Parfitt and Madison, 1993; Swartz et al., 1993; Stea et al., 1995), (2) inhibition of potassium channels (Barban et al., 1985; Storm, 1987; Doerner et al., 1988; Hoffman and Johnston, 1998), or (3) activation of exocytotic machinery downstream of $\mathrm{Ca}^{2+}$ influx (Capogna et al., 1995; Redman et al., 1997). However, there is no direct evidence to indicate which, if any, of the above targets are involved in the phorbol ester-induced synaptic potentiation (PESP). Furthermore, an involvement of PKC in the PESP has been questioned recently at some synapses, where certain PKC inhibitors had no effect on the PESP (Redman et al., 1997). It has been reported that Munc13-1, a mammalian homolog of Caenorhabditis elegans unc13p, has a diacylglycerol (DAG) receptor similar in affinity to PKC and is localized in the plasma membrane near the release site (Betz et al., 1998). Munc13-1 interacts with the vesicular protein Doc $2 \alpha$ in a DAGor phorbol ester-dependent manner (Orita et al., 1997). A possible involvement of Munc13-1 in PESP has been suggested at the amphibian neuromuscular junction in cell culture, where overexpression of Munc13-1 augmented the PESP (Betz et al., 1998).

The calyx of Held in the rodent auditory brainstem is a giant glutamatergic nerve terminal of anterior ventral cochlear neuron forming synapse onto the somata of principal cells of medial nucleus of trapezoid body (MNTB) (Barnes-Davies and For-

Received Feb. 18, 1999; revised June 3, 1999; accepted June 10, 1999.

This work was supported by the "Research for the Future" Program by The Japan Society for the Promotion of Sciences. We thank Drs. Masami Takahashi, Toshiya Manabe, Tetsuhiro Tsujimoto, and Brian Robertson for critically reading this manuscript.

Correspondence should be addressed to Tomoyuki Takahashi, Department of Neurophysiology, University of Tokyo Faculty of Medicine, Tokyo 113-0033, Japan. Copyright (C) 1999 Society for Neuroscience $0270-6474 / 99 / 197262-06 \$ 05.00 / 0$ sythe, 1995). Because of its large size, it is possible to make direct whole-cell recordings from the nerve terminal (Forsythe, 1994; Borst et al., 1995; Takahashi et al., 1996) and also to load molecules directly into it through a patch pipette (Takahashi et al., 1998). Taking advantage of this preparation, we have studied the mechanism underlying PESP. Our results indicate that neither calcium nor potassium conductances are involved in the presynaptic effect of phorbol ester, suggesting an involvement of the mechanism downstream of $\mathrm{Ca}^{2+}$ influx. By directly injecting the N-terminal peptide fragment of Doc $2 \alpha$ or the PKC inhibitor peptide into the calyceal nerve terminal, we have demonstrated that the Doc $2 \alpha$-Munc13-1 interaction as well as the PKC activation may mediate the PESP.

\section{MATERIALS AND METHODS}

Preparation and solutions. Transverse slices of the superior olivary complex were prepared from 14- to 16-d-old Wistar rats killed by decapitation under halothane anesthesia. The MNTB neurons and calyces were viewed with a $60 \times($ Olympus Optical, Tokyo, Japan) water immersion lens attached to an upright microscope (Axioskop; Zeiss). Each slice was superfused with artificial CSF (aCSF) containing (in mM): $120 \mathrm{NaCl}, 2.5$ $\mathrm{KCl}, 26 \mathrm{NaHCO}_{3}, 1.25 \mathrm{NaH}_{2} \mathrm{PO}_{4}, 2 \mathrm{CaCl}_{2}, 1 \mathrm{MgCl}_{2}, 10$ glucose, 0.5 myo-inositol, 2 sodium pyruvate, and 0.5 ascorbic acid, $\mathrm{pH} 7.4$, with $5 \%$ $\mathrm{CO}_{2}$ and $95 \% \mathrm{O}_{2}$. For recording EPSCs, the aCSF contained routinely bicuculline methiodide $(10 \mu \mathrm{M})$ and strychnine hydrochloride $(0.5 \mu \mathrm{M})$ to block spontaneous inhibitory synaptic currents. Effect of phorbol ester on

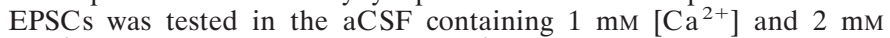
$\left[\mathrm{Mg}^{2+}\right]$. For recording presynaptic $\mathrm{Ca}^{2+}$ currents, $10 \mathrm{~mm}$ tetraethylammonium (TEA) chloride and $1 \mu \mathrm{M}$ tetrodotoxin (TTX) were included in the aCSF. For recording presynaptic $\mathrm{K}^{+}$current or spontaneous mEPSCs, $1 \mu \mathrm{M}$ TTX was included in the aCSF. For recording presynaptic action potentials, presynaptic pipettes were filled with the solution containing (in mM): 97.5 potassium gluconate, $32.5 \mathrm{KCl}, 10 \mathrm{HEPES}, 0.2$ EGTA, $1 \mathrm{MgCl}_{2}, 10$ potassium glutamate, 2 ATP (Mg salt), 12 phosphocreatine, and $0.5 \mathrm{GTP}, \mathrm{pH} 7.4$ adjusted with $\mathrm{KOH}$. For recording presynaptic $\mathrm{Ca}^{2+}$ currents, potassium gluconate and $\mathrm{KCl}$ in the presynaptic pipette solution were replaced by $110 \mathrm{~mm} \mathrm{CsCl}, 10 \mathrm{~mm}$ TEA chloride was added, and HEPES concentration was increased to $40 \mathrm{~mm}, \mathrm{pH} 7.4$ adjusted with $\mathrm{CsOH}$. For postsynaptic recordings, pipette solution contained (in mM): $110 \mathrm{CsF}, 30 \mathrm{CsCl}, 10 \mathrm{HEPES}, 5 \mathrm{EGTA}$, and $1 \mathrm{MgCl}_{2}$. 

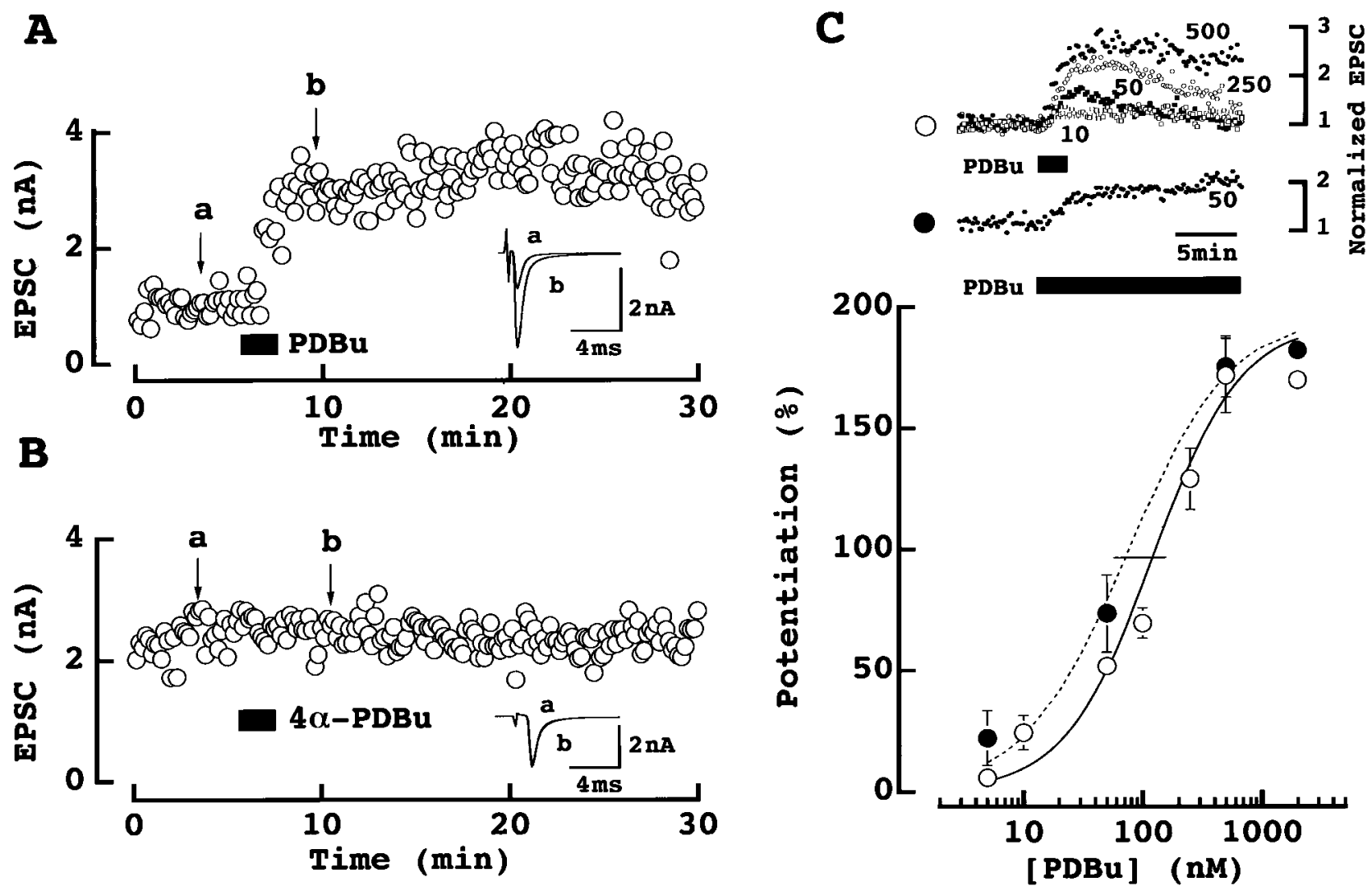

Figure 1. Phorbol ester potentiated the calyx-MNTB EPSCs. $A$, PDBu $(0.5 \mu \mathrm{M})$ bath-applied for 2 min (at a bar) potentiated the calyx-MNTB EPSCs evoked by extracellular stimulation. Six consecutive EPSCs before $(a)$ and after $(b)$ PDBu application are averaged and superimposed in inset. $B$, The inactive PDBu analog $4 \alpha$-PDBu $(0.5 \mu \mathrm{M})$ had no effect. $a$ and $b$ are as above. $C$, Dose-dependent potentiation of EPSCs by PDBu (5-2000 nM). Top column shows time plots of EPSC amplitude. Data from 4-6 experiments at each dose (10-500 nM) are normalized to the mean EPSC amplitude before PDBu application. PDBu was applied for $2 \mathrm{~min}(\bigcirc)$ or continuously $(50 \mathrm{nM}$; $)$. Bottom column shows dose-response curve of PDBu obtained by 2 min $(\bigcirc)$ or continuous $(-)$ applications. The magnitude of EPSCs 5-6 min after PDBu application was measured. Data points and error bars represent means and SEMs derived from 3-6 cells. Curves are fitted to the data points according to the following equation: magnitude of potentiation $(\%)=[$ maximal potentiation $] /\left[1+\left(\mathrm{EC}_{50} / \mathrm{PDBu} \text { concentration }\right)^{\mathrm{n}}\right]$, where maximal potentiation was 194 and $195 \%$ each for 2 min $(\bigcirc)$ and continuous $(\bullet)$ application. $\mathrm{EC}_{50}$ (indicated by a horizontal bar) was $121 \mathrm{~nm}(\bigcirc)$ and $75 \mathrm{~nm}(\bullet)$, respectively. Hill coefficient was $1.2(\bigcirc)$ and $1.0(\bullet)$, respectively.

When the aCSF did not contain TTX, $N$-(2,6-diethylphenylcarbamoylmethyl)-triethylammonium bromide (QX314; $5 \mathrm{~mm}$ ) was included in the postsynaptic pipette solution to suppress action potential generation.

Data recording and analysis. Whole-cell patch-clamp recordings were made from MNTB principal neurons, presynaptic calyces, or simultaneously from both structures. EPSCs were evoked at $0.1 \mathrm{~Hz}$ throughout by extracellular stimulation of presynaptic axons using a bipolar platinum electrode positioned near the midline of a relatively thick slice $(200 \mu \mathrm{m})$ or by presynaptic action potentials elicited directly by a whole-cell pipette in thin slices $(150 \mu \mathrm{m})$. The resistance of patch pipette was 4-7 M $\Omega$ for presynaptic recordings and 2-4 M $\Omega$ for postsynaptic recordings. The series resistance of presynaptic recording was typically $10-20 \mathrm{M} \Omega$ and was compensated by $70-90 \%$ in voltage-clamp experiments. Current or potential recordings were made with a patch-clamp amplifier (Axopatch 200B; Axon Instruments, Foster City, CA). Records were low-passfiltered at $2.5-20 \mathrm{kHz}$ and digitized at $5-50 \mathrm{kHz}$ by a CED 1401 interface (Cambridge Electronic Design). Presynaptic voltage-gated currents were leak-subtracted by using a scaled pulse divided by $n(\mathrm{P} / \mathrm{N})$ protocol (Forsythe et al., 1998; Takahashi et al., 1998). The magnitude of potentiation of EPSCs was evaluated from the mean amplitude of six consecutive events during 5-6 min after phorbol ester application divided by that of six events before application. Values in the text and figures are given as means \pm SEM, and significance of difference was evaluated by one-way ANOVA or Kolmogorov-Smirnov test (for cumulative histograms) with 0.05 taken as the level of significance.

Drug application. Drugs were bath-applied by switching superfusates using solenoid valves. Peptides were injected into calyces through a superfusion tube directly installed in a presynaptic patch pipette. The superfusion tube was fabricated from an Eppendorf yellow tip heated and pulled to make an outer tip diameter of 50-70 $\mu \mathrm{m}$. After back-filling the tube with pipette solutions containing synthetic peptides, it was inserted into a patch pipette with its tip 500-600 $\mu \mathrm{m}$ behind the tip of patch pipette. After obtaining control responses, the dialysis solution was delivered into presynaptic patch pipette with positive pressure manually applied through a syringe. When a fluorescence dye Lucifer yellow $(0.05 \%)$ was injected by this method, fluorescence became detectable in a calyx within 1 min after injection and reached maximal intensity within 4 min. When FITC-conjugated albumin was injected, the whole calyx was stained within $5 \mathrm{~min}$. The amino acid sequence of synthetic Mid peptide and mutated Mid peptide is IQEHMAINCPGPIRPIRQISDYFP and IYKDWAFNVCPGPIRPIRQISDYFP, respectively (Orita et al., 1997). PKC inhibitor peptide, PKCI (19-36), Mid peptide, or mutated Mid peptide was dissolved in pipette solution at $200 \mu \mathrm{M}$ and loaded into calyces through the superfusion tube. Experiments were carried at room temperature $\left(22-26^{\circ} \mathrm{C}\right)$.

\section{RESULTS}

\section{Potentiation of EPSCs by phorbol esters}

As illustrated in Figure $1 A$, phorbol ester markedly potentiated the calyx-MNTB EPSCs as reported at other synapses (Malenka et al., 1986; Shapira et al., 1987). During bath-application of phorbol 1,2-dibutrate (PDBu; $0.5 \mu \mathrm{M}$ for $2 \mathrm{~min}$ ), EPSCs became larger reaching a maximal size within 5 min after application. The mean magnitude of this potentiation was $162 \pm 37 \%$ ( \pm SEM; $n=6$ cells, see also Fig. $5 A$ ). The potentiation by PDBu 

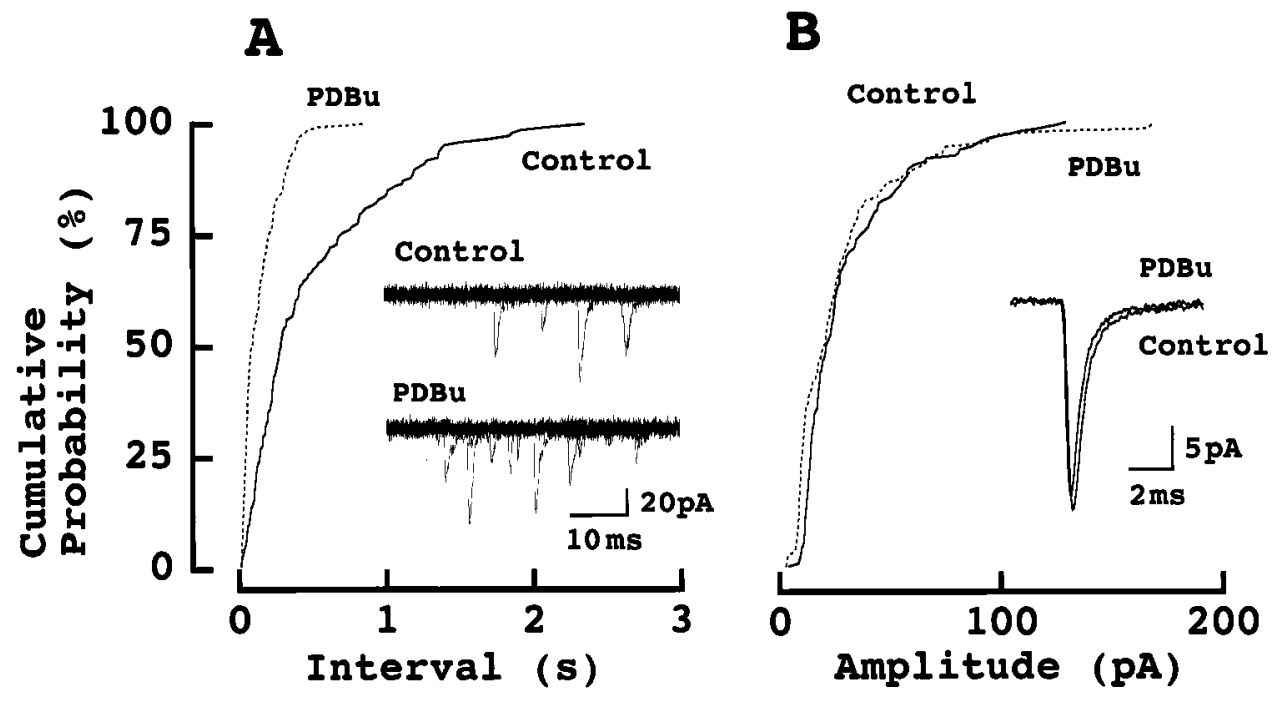

Figure 2. Phorbol ester increased the frequency of mEPSCs but had no effect on the amplitude of mEPSCs. $A$, Cumulative interval histograms of mEPSCs recorded from an MNTB principal cell under TTX Each 200 events were sampled before (control) and 5 min after PDBu $(0.5 \mu \mathrm{M})$ application. Ten consecutive records before and $6 \mathrm{~min}$ after $\mathrm{PDBu}$ application are superimposed in inset. B, Cumulative amplitude histogram of mEPSCs from the same cell. Superimposed records in inset are averaged EPSCs of 200 events each before and after PDBu application. No significant difference in the amplitude of mEPSCs between PDBu and control in Kolmogorov-Smirnov test.

at this concentration lasted for $>20$ min with no sign of decline. Other phorbol esters such as phorbol-12,13-diacetate or phorbol12-myristate-13 acetate produced a similar potentiating effect (both at $0.5 \mu \mathrm{M}$; data not shown) but the inactive $4 \alpha$-PDBu $(0.5$ $\mu \mathrm{M})$ had no effect $(-0.8 \pm 9.9 \% ; n=7$; Fig. $1 B)$. The potentiating effect of PDBu on EPSCs was dose-dependent (Fig. 1C) with a maximum potentiation reached at around $0.5 \mu \mathrm{M}$ and the $50 \%$ effective dose $\left(\mathrm{EC}_{50}\right)$ being $121 \mathrm{~nm}$ with a 2 min application. Potentiation of EPSCs was transient when low doses of PDBu were applied for 2 min, but it was sustained when $\mathrm{PDBu}$ was continuously applied. The $\mathrm{EC}_{50}$ of continuously applied $\mathrm{PDBu}$ was $75 \mathrm{nM}$.

\section{Effects of phorbol ester on quantal EPSCs}

We subsequently examined the effect of PDBu on spontaneous miniature (m) EPSCs recorded in the presence of TTX $(1 \mu \mathrm{M}$; Fig. 2). As shown in cumulative interval histograms, PDBu (0.5 $\mu \mathrm{M})$ increased the mean frequency of mEPSCs $(6.7 \pm 3 \mathrm{~Hz})$ on average by $2.1 \pm 0.5$-fold $(n=5$; Fig. $2 A)$. In contrast, neither the kinetics nor the amplitude of mEPSCs was significantly affected by PDBu (Fig. 2B). The mean amplitude of mEPSCs after PDBu application was $102 \pm 2.9 \%(n=6)$ of control before PDBu application, suggesting that this phorbol ester had no effect on postsynaptic glutamate receptor sensitivity. Thus, as reported at other synapses (Malenka et al., 1986; Shapira et al., 1987), the site of its action must be purely presynaptic.

\section{Lack of phorbol ester effect on presynaptic calcium currents}

Previous studies on somatic or recombinant $\mathrm{Ca}^{2+}$ currents indicate that phorbol ester can enhance $\mathrm{Ca}^{2+}$ currents (Fossier et al., 1990; O'Dell and Alger, 1991; Parfitt et al., 1993; Stea et al., 1995). It was then speculated that a similar potentiation might occur at the presynaptic nerve terminals. We have directly tested this possibility by recording the presynaptic $\mathrm{Ca}^{2+}$ currents from the giant nerve terminal, the calyx of Held. The $\mathrm{Ca}^{2+}$ currents at the calyx have been pharmacologically identified as P-type (Forsythe et al., 1998; Iwasaki and Takahashi, 1998), and they can be attenuated by agonists of metabotropic glutamate receptors (Takahashi et al., 1996) or $\mathrm{GABA}_{\mathrm{B}}$ receptors (Takahashi et al., 1998). As illustrated in Figure 3, PDBu $(0.5 \mu \mathrm{M})$ had no effect on presynaptic $\mathrm{Ca}^{2+}$ currents at all membrane potential examined, with the mean magnitude of $\mathrm{Ca}^{2+}$ currents at $-10 \mathrm{mV}$ being

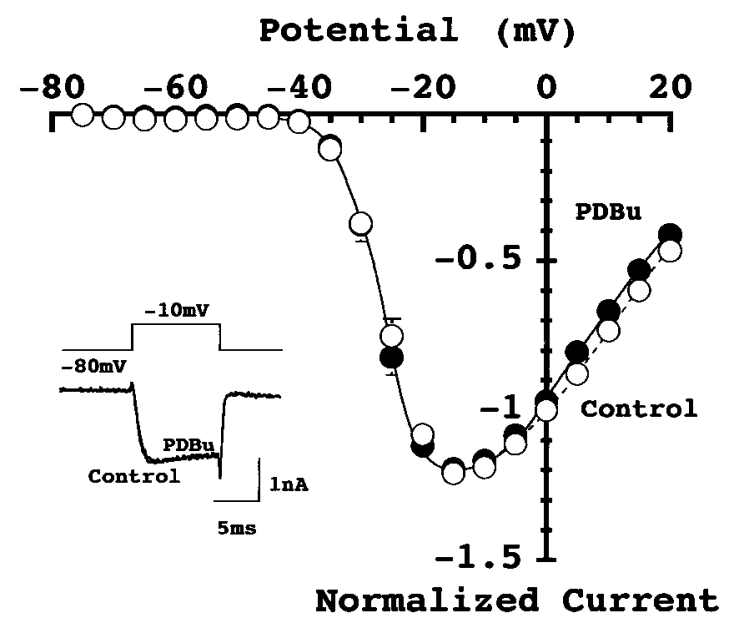

Figure 3. Phorbol ester had no effect on presynaptic calcium currents. Voltage-dependent $\mathrm{Ca}^{2+}$ currents were evoked in calyceal presynaptic terminals by a depolarizing pulse from $-80 \mathrm{mV}$ holding potential to -10 $\mathrm{mV}$ before and after PDBu application $(0.5 \mu \mathrm{M}$, two traces superimposed in inset). The $\mathrm{Ca}^{2+}$ current-voltage relationships before (-) and 6-9 min after (O) PDBu application. Data points and error bars are means and SEMs of $\mathrm{Ca}^{2+}$ current amplitude from five calyces. The mean amplitude of $\mathrm{Ca}^{2+}$ currents at $-10 \mathrm{mV}$ was $928 \pm 9.4 \mathrm{pA}$ in control and $904 \pm 7.3$ $\mathrm{pA}$ after PDBu application $(n=5)$. Lines are drawn by eyes in this and the next figure.

$98 \pm 3 \%$ of control $(n=5)$. These results indicate that the PESP is not mediated by presynaptic $\mathrm{Ca}^{2+}$ channels, at least at this mammalian brainstem synapse.

\section{Presynaptic potassium currents are unaffected by phorbol ester}

Voltage-gated potassium channel currents in hippocampal neurons are attenuated by phorbol esters (Barban et al., 1985; Storm, 1987; Doerner et al., 1988; Hoffman and Johnston, 1998). If phorbol ester attenuates presynaptic potassium channels, this would presumably lead to increased $\mathrm{Ca}^{2+}$ influx, thereby enhancing transmitter release. We have tested this possibility by recording presynaptic potassium currents. As shown in Figure 4, PDBu $(0.5 \mu \mathrm{M})$ had no effect on the presynaptic voltage-dependent potassium currents. The mean amplitude of potassium current at $0 \mathrm{mV}$ was $4.7 \pm 0.4 \mathrm{nA}$ in control and $4.9 \pm 0.5 \mathrm{nA}$ after $\mathrm{PDBu}$ 


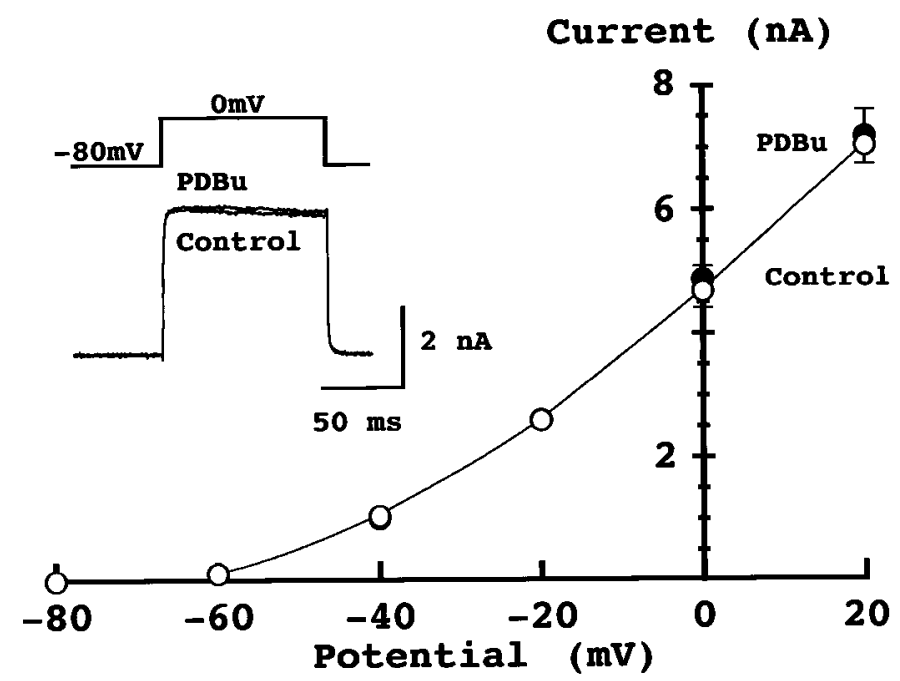

Figure 4. Phorbol ester had no effect on presynaptic potassium currents. Voltage-dependent $\mathrm{K}^{+}$currents recorded from the calyx of Held in the presence of TTX. Potassium currents were evoked by a depolarizing pulse from $-80 \mathrm{mV}$ holding potential to $0 \mathrm{mV}$ before and after PDBu application (superimposed in inset). The $\mathrm{K}^{+}$current-voltage relationships before $(\bigcirc)$ and 5-7 min after $(\bullet)$ PDBu application. Data points and error bars derived from five calyces each.

application $(n=5)$. It has been also reported that G-proteincoupled inward rectifying potassium (GIRK) conductance can be suppressed by PKC activation (Takano et al., 1995). Although any change in GIRK can be revealed as a change in holding current (Takahashi et al., 1998), PDBu had no effect on the holding current (98.9 $\pm 5.7 \% ; n=5$ ), suggesting that GIRK is not involved in the PESP. These results indicate that neither the calcium conductance nor potassium conductance in the presynaptic terminal is involved in the PESP at this synapse. Therefore, the target of phorbol ester must be downstream of $\mathrm{Ca}^{2+}$ influx as has been suggested for secretory cells (Gillis et al., 1996).

\section{Involvement of PKC in phorbol ester-induced synaptic potentiation}

To address whether PKC is involved in the effect of phorbol esters, we tested a number of PKC inhibitors on PESP. Bisindolylmaleimid (BIS; $1 \mu \mathrm{M}$ ), a competitive inhibitor for the ATPbinding site of PKC, partially but significantly attenuated the phorbol ester-induced synaptic facilitation (Fig. $5 A$ ). Potentiation of EPSCs 5-6 min after application of PDBu $(0.5 \mu \mathrm{M})$ was $64 \pm$ $9.6 \%(n=5)$ in the presence of BIS, whereas it was $162 \pm 37 \%$ $(n=6)$ in control (see above). Calphostin C $(0.5 \mu \mathrm{M})$, a competitive inhibitor for the phorbol ester-binding site of PKC, also significantly suppressed the PESP with the potentiation being $48 \pm 24 \%(n=3)$ in its presence (data not shown). A more specific tool to test an involvement of $\mathrm{PKC}$ is the $\mathrm{PKC}$ inhibitor peptide (PKCI; 19-36), which acts as a pseudosubstrate for PKC. We injected PKCI into the calyceal presynaptic nerve terminals during paired presynaptic and postsynaptic whole-cell recordings. EPSCs were evoked by presynaptic action potentials elicited in calyceal nerve terminals with a patch pipette (Takahashi et al., 1996; 1998). In control experiments, externally applied PDBu $(0.5$ $\mu \mathrm{M})$ potentiated EPSCs (Fig. $5 B)$ with a magnitude $(138 \pm 29 \%$; $n=5$ ) comparable to that observed for the extracellularly evoked EPSCs (no significant difference). When PKCI was injected into the calyx, the peptide by itself had no effect on EPSCs (data not shown), but PESP was significantly attenuated, with the magni-
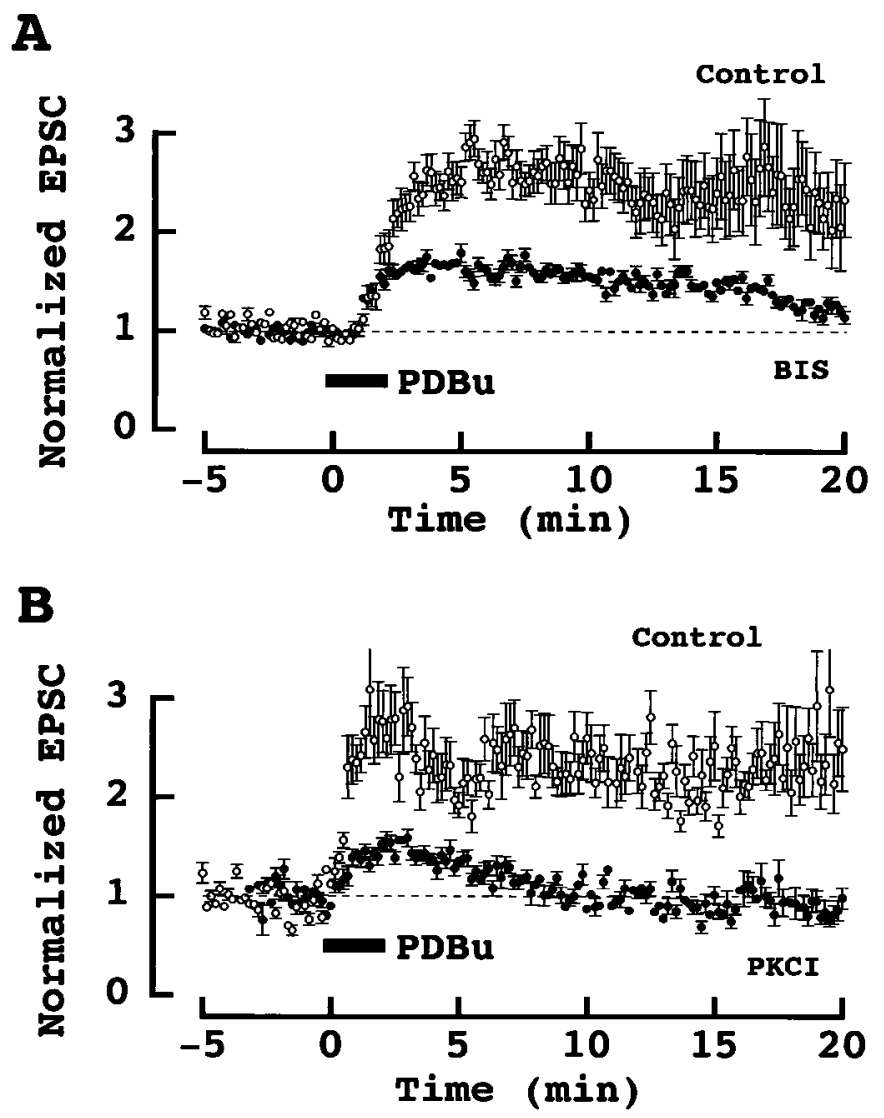

Figure 5. PKC inhibitors attenuated PESP. A, Effect of PDBu $(0.5 \mu \mathrm{M})$ on EPSCs in the presence $(\bullet)$ and absence $(\bigcirc)$ of the PKC inhibitor BIS $(1 \mu \mathrm{M})$. BIS was applied 5-10 min before PDBu. Mean amplitude and SEMs (error bars) derived from six (control) and five (BIS) cells are shown. EPSCs were evoked extracellularly. $B$, Effect of PDBu on EPSCs evoked by presynaptic action potentials in the presence $(\bullet)$ and absence (O) of the PKC inhibitor peptide (PKCI 19-36) in paired presynaptic and postsynaptic whole-cell recordings. PKCI had been injected into caclyceal presynaptic terminals 5-10 min before PDBu applications. Data derived from five cells each for control and PKCI-loaded calyces. Dashed lines indicate baselines derived from the mean amplitude of EPSCs before $\mathrm{PDBu}$ application in this and the next figure.

tude of potentiation being only $27 \pm 12 \%(n=5$; Fig. $5 B)$. Taken together, these results suggest that PKC is involved in the phorbol ester-induced synaptic potentiation.

\section{Involvement of Doc2 $\alpha$-Munc13-1 interaction in phorbol ester-induced synaptic potentiation}

We next examined the possibility that the Doc 2 $\alpha$-Munc13-1 interaction (Orita et al., 1997) underlies the PESP. For this purpose, we injected into the calyx a synthetic peptide corresponding to the N-terminal domain of Doc $2 \alpha$, which interacts with Munc13-1 (the Mid domain: amino acid residues 13-37, see Materials and Methods). This Mid peptide alone blocks Doc $2 \alpha$-Munc13-1 interaction in vitro (Orita et al., 1997) and also blocks synaptic transmission when injected into presynaptic neurons in culture (Mochida et al., 1998). In contrast, at the calyx of Held synapse, Mid peptide had no appreciable effect on EPSCs (Fig. 6A), with the amplitude of EPSCs remaining as $116 \pm 11 \%$ $(n=7) 10 \mathrm{~min}$ after injection. However, in the presence of Mid, potentiation of EPSCs by PDBu was significantly attenuated in amplitude and no longer sustained (Fig. 6A). The magnitude of PESP 5 min after Mid application was $64 \pm 6.2 \%(n=7$ vs $138 \pm$ 

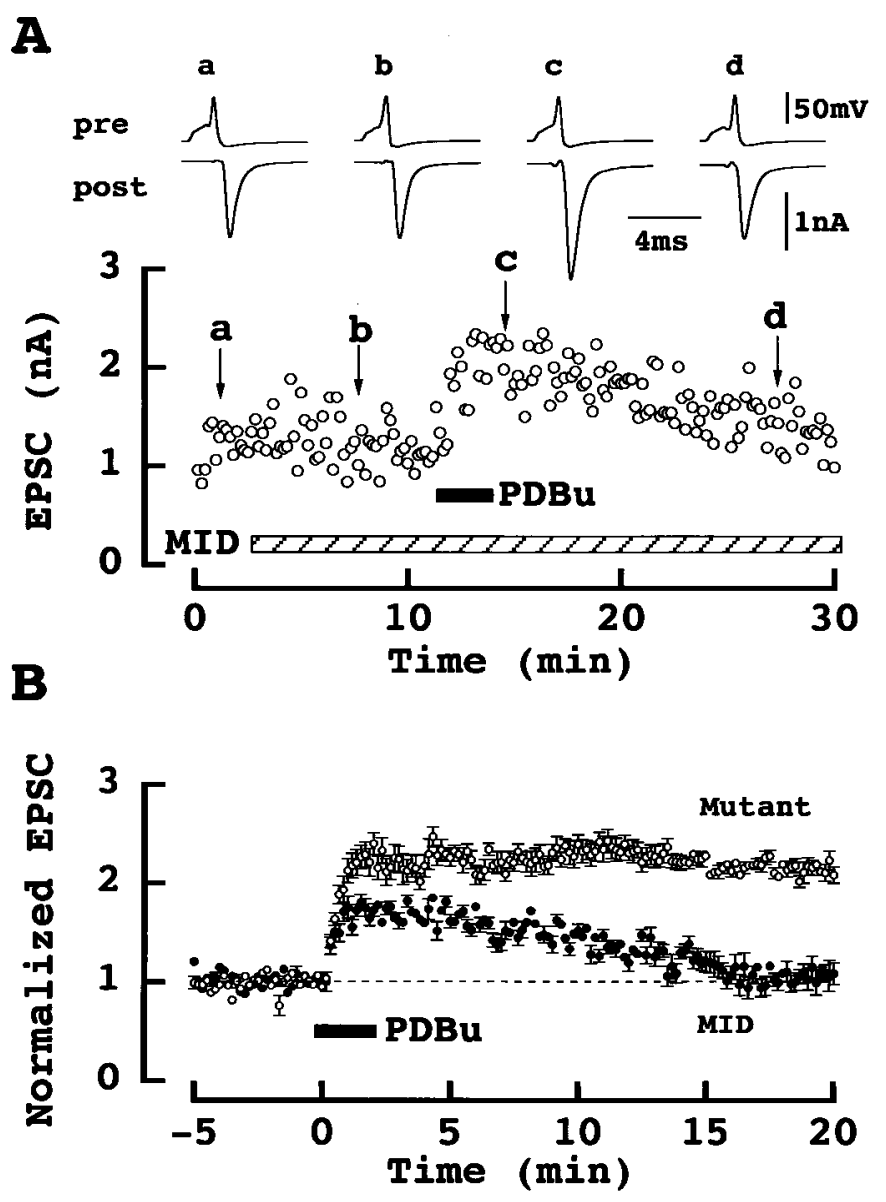

Figure 6. Mid peptide attenuated PESP. A, Synthetic Mid peptide (Mid) had no effect on EPSCs (bottom sample records) evoked by presynaptic action potentials (top records) in simultaneous presynaptic and postsynaptic whole-cell recording at a calyx-MNTB synapse. Sample records were averaged from six events before $(a)$ and 5 min after $(b)$ Mid application, and $2 \mathrm{~min}(c)$ and $18 \mathrm{~min}(d)$ after PDBu application. $B$, Effect of PDBu on EPSCs at calyces loaded with Mid (O) or mutated Mid (○). Data derived from seven cells for Mid and five cells for mutated Mid. The difference was significant between Mid and mutated Mid and also between Mid and control (Fig. 5B; $\bigcirc$ ), but not significant between the mutated Mid and control (Fig. 5B; $\bigcirc$; one-way ANOVA).

$29 \%$ in control, see above). As a control, we employed a mutated Mid peptide, which has no effect on Doc $2 \alpha$-Munc13-1 interaction (Mochida et al., 1998). When the mutated Mid peptide was similarly loaded into calyces, PESP was not attenuated (124 \pm $15 \% ; n=5$; Fig. $6 B$ ).

\section{DISCUSSION}

At the brainstem auditory synapse formed by the calyx of Held, we have studied the facilitatory effect of phorbol ester on synaptic transmission. As reported previously (Malenka et al., 1986; Shapira et al., 1987; but see Caroll et al., 1998), phorbol ester had no effect on the amplitude of spontaneous miniature EPSCs, confirming that the site of its action is predominantly presynaptic. Direct whole-cell recordings from the calyx of Held indicated that phorbol ester had no effect on presynaptic $\mathrm{Ca}^{2+}$ currents. It has been reported that phorbol ester has no effect on recombinant $\mathrm{Ca}^{2+}$ channels containing $\alpha_{1 \mathrm{~A}}$ subunit, but enhances $\mathrm{Ca}^{2+}$ channels containing $\alpha_{1 \mathrm{~B}}$ subunit (Stea et al., 1995). Since $\mathrm{Ca}^{2+}$ channels triggering transmitter release at the calyx of Held are pre- dominantly P-type containing $\alpha_{1 \mathrm{~A}}$ subunits (Forsythe et al., 1998; Iwasaki and Takahashi, 1998), possible involvement of $\mathrm{N}\left(\alpha_{1 \mathrm{~B}}\right)$ type $\mathrm{Ca}^{2+}$ channels in PESP at other synapses cannot be excluded from the present study (but see Yawo, 1999). Our results also indicate that phorbol ester has no effect on presynaptic $\mathrm{K}^{+}$ currents. Thus, the mechanism for PESP must reside at the downstream of $\mathrm{Ca}^{2+}$ influx as in secretory cells, where phorbol ester increases hormonal secretion without involving a change in intracellular $\mathrm{Ca}^{2+}$ concentration (Gillis et al., 1996).

In chromaffin cells (Gillis et al., 1996), retinal bipolar cells (Minami et al., 1998), and hippocampal synapses in culture (Stevens and Sullivan 1998), phorbol ester is postulated to increase the size of the releasable pool of synaptic vesicles by accelerating replenishment from a "reservoir pool" (but see Yawo, 1999). What then might be the molecular target of phorbol esters? Diacylglycerol (DAG) and phorbol esters bind to the regulatory $\mathrm{C}_{1}$-domain of $\mathrm{PKC}$ and anchor the enzyme to the plasma membrane, thereby stabilizing its active conformation (Newton, 1997). The phorbol ester-induced synaptic facilitation was attenuated by bath-application of PKC inhibitors BIS or calphostin $\mathrm{C}$ and also by the PKC inhibitory peptide directly injected into the calyx through whole-cell recording pipette. These results suggest that PKC is involved, at least in part, in the PESP. However, in spite of relatively high concentrations, the blocking effect of PKC inhibitors was incomplete, implying that there may be an additional mechanism mediating the effect of phorbol ester. While an involvement of PKC in the PESP has been suspected (Scholfield and Smith, 1989; Redman et al., 1997), it was recently reported that phorbol esters or DAG stimulates the vesicular protein $\operatorname{Doc} 2 \alpha$ to interact with the plasma membrane-associated protein Munc13-1 (Orita et al., 1997). The $\mathrm{N}$-terminal domain (Mid) of Doc $2 \alpha$ is involved in this interaction. We have demonstrated that the synthetic Mid peptide introduced into the calyx of Held attenuates PESP. This effect appears specific since the mutated Mid peptide had no effect. Therefore, we conclude that the Doc $2 \alpha$-Munc13-1 interaction is also involved in the PESP. In line with our results, it has been reported that presynaptic over-expression of Munc13-1 enhanced phorbol ester-dependent synaptic potentiation at Xenopus neuromuscular junctions in culture (Betz et al., 1998).

Apart from interaction with Doc2 $\alpha$, Munc13-1 can also interact with N-terminal of syntaxin 1, a SNARE protein thought to be involved in synaptic vesicle fusion (Betz et al., 1997). On the other hand, PKC can phosphorylate another SNARE protein, SNAP-25 (Fujita et al., 1996; Shimazaki et al., 1996), thereby stimulating catecholamine release from PC12 cells (Shimazaki et al., 1996). Furthermore, PKC can phosphporylate Munc-18, which interacts with SNARE proteins. Thus the SNARE protein may be a common effector downstream of PKC and Munc13-1 for the phorbol ester-induced synaptic potentiation.

Munc13-1 is a mammalian homolog of C. elegans unc-13p and, by analogy, is thought to contribute to vesicle docking and exocytosis. In support of this hypothesis, Mochida et al. (1998) showed that Mid peptide blocked synaptic transmission when injected into the presynaptic neuron in culture. However, this effect was not observed at the calyx of Held, where the peptide was directly injected into the nerve terminal through patch pipette perfusion. Since the blocking effect of Mid at cultured synapses appears slow and activity-dependent (Mochida et al., 1998), Munc13-1 might be involved in vesicular replenishing process rather than exocytotic process. It is also possible that exocytotic machineries are different between synapses. 


\section{REFERENCES}

Barban JM, Snyder SH, Alger BE (1985) Protein kinase C regulates ionic conductance in hippocampal pyramidal neurons: electrophysiological effects of phorbol esters. Proc Natl Acad Sci USA 82:2538-2542.

Barnes-Davies M, Forsyhe ID (1995) Pre- and postsynaptic glutamate receptors at a giant excitatory synapse in rat auditory brainstem slices. J Physiol (Lond) 488:387-406.

Betz A, Okamoto M, Benseler F, Brose N (1997) Direct interaction of the rat unc-13 homologue Munc 13-1 with the $\mathrm{N}$ terminus of syntaxin. J Biol Chem 272:2520-2526.

Betz A, Ashery U, Rickmann M, Augustin I, Neher E, Sudhof T, Rettig J, Brose N (1998) Munc13-1 is a presynaptic phorbol ester receptor that enhances neurotransmitter release. Neuron 21:123-136.

Borst JGG, Helmchen F, Sakmann B (1995) Pre- and postsynaptic whole-cell recordings in the medial nucleus of the trapezoid body of the rat. J Physiol (Lond) 489:825-840.

Capogna M, Gahwiler BH, Thompson SM (1995) Presynaptic enhancement of inhibitory synaptic transmission by protein kinases $\mathrm{A}$ and $\mathrm{C}$ in the rat hippocampus in vitro. J Neurosci 15:1249-1260.

Carroll RC, Nicoll RA, Malenka RC (1998) Effects of PKA and PKC on miniature excitatory postsynaptic currents in CA1 pyramidal cells. J Neurophysiol 80:2797-2800.

Doerner D, Pitler TA, Alger BE (1988) Protein kinase C activators block specific calcium and potassium current components in isolated hippocampal neurons. J Neurosci 8:4069-4078.

Forsythe ID (1994) Direct patch recording from identified presynaptic terminals mediating glutamatergic EPSCs in the rat CNS, in vitro. J Physiol (Lond) 479:381-387.

Forsythe ID, Tsujimoto T, Barnes-Davies M, Cuttle MF, Takahashi T (1998) Inactivation of presynaptic calcium current contributes to synaptic depression at a fast central synapse. Neuron 20:797-807.

Fossier P, Baux G, Tauc L (1990) Activation of protein kinase C by presynaptic FLRFamide receptors facilitates transmitter release at an Aplysia cholinergic synapse. Neuron 5:479-486.

Fujita Y, Sasaki T, Fukui K, Kotani H, Kimura T, Hata Y, Sudhof TC, Scheller RH, Takai Y (1996) Phosphorylation of Munc-18/n-Sec1/rbSec1 by protein kinase C. J Biol Chem 271:7265-7268.

Gillis KD, Mossner R, Neher E (1996) Protein kinase C enhances exocytosis from chromaffin cells by increasing the size of the readily releasable pool of secretory granules. Neuron 16:1209-1220.

Hoffman DA, Johnston D (1998) Downregulation of transient $\mathrm{K}^{+}$channels in dendrites of hippocampal CA1 pyramidal neurons by activation of PKA and PKC. J Neurosci 18:3521-3528.

Iwasaki S, Takahashi T (1998) Developmental changes in calcium channel types mediating synaptic transmission in rat auditory brainstem. J Physiol (Lond) 509:419-423.

Malenka RC, Madison DV, Nicoll RA (1986) Potentiation of synaptic transmission in the hippocampus by phorbol esters. Nature 321:175-177.

Minami N, Berglund K, Sakaba T, Kohmoto H, Tachibana M (1998)
Potentiation of transmitter release by protein kinase $\mathrm{C}$ in goldfish retinal bipolar cells. J Physiol (Lond) 512:219-225.

Mochida S, Orita S, Sakaguchi G, Sasaki T, Takai Y (1998) Role of the Doc $2 \alpha$ - Munc13-1 interaction in the neurotransmitter release process. Proc Natl Acad Sci USA 95:11418-11422.

Newton AC (1997) Regulation of protein kinase C. Curr Opin Cell Biol 9:161-167.

O'Dell T J, Alger BE (1991) Single calcium channels in rat and guineapig hippocampal neurons. J Physiol (Lond) 436:739-767.

Orita S, Naito A, Sakaguchi G, Maeda M, Igarashi H, Sasaki T, Takai, Y (1997) Physical and functional interactions of Doc2 and Munc13 in $\mathrm{Ca}^{2+}$-dependent exocytotic machinery. J Biol Chem 272:16081-16084.

Parfitt KD, Madison DV (1993) Phorbol esters enhance synaptic transmission by a presynaptic, calcium-dependent mechanism in rat hippocampus. J Physiol (Lond) 471:245-268.

Redman RS, Searl TJ, Hirsh JK, Silinsky EM (1997) Opposing effects of phorbol esters on transmitter release and calcium currents at frog motor nerve endings. J Physiol (Lond) 501:41-48.

Scholfield CN, Smith AJ (1989) A phorbol diester-induced enhancement of synaptic transmission in olfactory cortex. $\mathrm{Br} \mathrm{J}$ Pharmacol 98:1344-1350.

Shapira R, Silberberg SD, Ginsburg S, Rahamimoff R (1987) Activation of protein kinase $\mathrm{C}$ augments evoked transmitter release. Nature 325:58-60.

Shimazaki Y, Nishiki T, Omori A, Sekiguchi M, Kamata Y, Kozaki S, Takahashi M (1996) Phosphorylation of 25-kDa synaptosomeassociated protein. Possible involvement in protein kinase $\mathrm{C}$-mediated regulation of neurotransmitter release. J Biol Chem 271:14548-14553.

Stea A, Soong TW, Snutch TP (1995) Determinants of PKC-dependent modulation of a family of neuronal calcium channels. Neuron 15:929-940.

Stevens CF, Sullivan JM (1998) Regulation of the readily releasable vesicle pool by protein kinase C. Neuron 21:885-893.

Storm JF (1987) Phorbol ester broaden the action potential in CA1 hippocampal pyramidal cells. Neurosci Lett 75:71-74.

Swartz KJ, Merritt A, Bean BP, Lovinger DM (1993) Protein kinase C modulates glutamate receptor inhibition of $\mathrm{Ca}^{2+}$ channels and synaptic transmission. Nature 361:165-168.

Takahashi T, Forsythe ID, Tsujimoto T, Barnes-Davies M and Onodera K (1996) Presynaptic calcium current modulation by a metabotropic glutamate receptor. Science 274:594-597.

Takahashi T, Kajikawa Y, Tsujimoto T (1998) G-protein-coupled modulation of presynaptic calcium currents and transmitter release by a $\mathrm{GABA}_{\mathrm{B}}$ receptor. J Neurosci 18:3138-3146.

Takano K, Stanfield PR, Nakajima S, Nakajima Y (1995) Protein kinase C-mediated inhibition of an inward rectifier potassium channel by substance P in nucleus basalis neurons. Neuron 14:999-1008.

Yawo H (1999) Protein kinase C potentiates transmitter release from the chick ciliary presynaptic terminal by increasing the exocytotic fusion probability. J Physiol (Lond) 515:169-180. 